\title{
PENGARUH PENGETAHUAN, SIKAP DAN DUKUNGAN KELUARGA TERHADAP DIET HIPERTENSI DI DESA HULU KECAMATAN PANCUR BATU TAHUN 2016
}

\author{
Almina Rospitaria Tarigan ${ }^{1}$, Zulhaida Lubis ${ }^{2}$, Syarifah ${ }^{3}$ \\ ${ }^{1}$ Alumni Pascasarjana Ilmu Kesehatan Masyarakat Universitas Sumatera Utara \\ 2Staf Pengajar Fakultas Kesehatan Masyarakat Universitas Sumatera Utara \\ *regaar56@yahoo.co.id
}

DOI : 10.24252/jkesehatan.v11i1.5107

\begin{abstract}
Abstrak
Hipertensi merupakan faktor risiko utama penyebab kematian. Desa Hulu adalah desa yang memiliki jumlah penderita hipertensi tertinggi di Puskesmas Pancur Batu, Kabupaten Deli Serdang. Penderita hipertensi pada tahun 2014, berjumlah 44, 2015, berjumlah 56 orang dan pada tahun 2016 berjumlah 108 orang. Tujuan penelitian ini untuk menganalisis pengaruh pengetahuan, sikap dan dukungan keluarga terhadap pelaksanaan diet hipertensi di desa kecamatan Batu Pancur Hulu. Penelitian ini merupakan penelitian cross-sectional dengan pendekatan explanatory. Penelitian ini dilakukan antara bulan April dan Juni 2016 dengan populasi dalam penelitian ini adalah semua pasien hipertensi di desa kecamatan Batu Pancur Hulu berjumlah 108 orang dan seluruh populasi dijadikan sampel. Data diperoleh dengan wawancara kuesioner, dianalisis dengan regresi logistik ganda pada $\alpha=0,05$. Hasil penelitian menunjukkan bahwa secara statistik pengetahuan (hipertensi diet, hipertensi asupan makanan) dan sikap terhadap (hipertensi diet, diet hipertensi diet) dan dukungan keluarga meliputi (dukungan harapan, dukungan nyata, dukungan informasi, dukungan emosional) pengaruh yang signifikan terhadap pelaksanaan dari diet hipertensi di desa Hulu kecamatan Batu Pancur. Pengaruh variabel pengetahuan lebih besar pada pelaksanaan diet hipertensi.
\end{abstract}

Kata Kunci : Pengetahuan, Sikap, Dukungan Keluarga, Diet Hipertensi.

\begin{abstract}
Hypertension is a major risk factor causes of death. Hulu village is a village that has the highest number of hypertensive patients in Puskesmas Pancur Batu, Deli Serdang regency. Patients with hypertension in 2014, totaling 44, 2015, amounted to 56 people and in 2016 amounted to 108 people. This study aimed to analyze the influence of knowledge, attitude and family support for the implementation of hypertension diet in the village of Batu Pancur Hulu subdistrict. The study was crosssectional study with explanatory approach. This study was conducted between April and June 2016. The population in the study were all patients with hypertension in the village of Batu Pancur Hulu subdistrict totaled 108 people and the entire population sampled. The data were obtained by questionnaire interviews, analyzed by multiple logistic regression at $a=0.05$. The results showed that statistically the knowledge of (diet hypertension, food intake hypertension) and attitudes toward (diet hypertension, dietary diet hypertension) and family support include (support hope, real support, information support, emotional support) a significant effect on the implementation of the diet hypertension in the village of
\end{abstract}


Hulu subdistrict Pancur Stone. Variables knowledge greater impact on the implementation of hypertension diet.

\section{Keywords : Knowledge, Attitude, Family Support, Implementation Hypertension Diet}

\section{PENDAHULUAN}

Hipertensi atau yang dikenal dengan nama penyakit darah tinggi adalah suatu keadaan dimana terjadi peningkatan tekanan darah di atas ambang batas normal yaitu 120/80 mmHg. Menurut WHO (Word Health Organization), batas tekanan darah yang dianggap normal adalah kurang dari 130/85 mmHg. Bila tekanan darah sudah lebih dari 140/90 mmHg dinyatakan hipertensi (batas tersebut untuk orang dewasa di atas 18 tahun) (Adib, 2009).

Hipertensi dapat diklasifikasikan menjadi 2 jenis, yaitu hipertensi primer atau esensial (90\% kasus hipertensi) yang penyebabnya tidak diketahui dan hipertensi sekunder $(10 \%)$ yang disebabkan oleh penyakit ginjal, penyakit endokrin, penyakit jantung dan gangguan ginjal. Menurut JNC VII Report 2003, diagnosis hipertensi ditegakkan apabila didapatkan tekanan darah sistolik (TDS) $\geq 140 \mathrm{mmHg}$ dan atau tekanan darah diastolik (TDD) $\geq 90 \mathrm{mmHg}$ pada dua kali pengukuran dalam waktu yang berbeda (Indrayani, 2009).

Penyakit hipertensi tahun demi tahun terus mengalami peningkatan. Tidak hanya di Indonesia, namun juga di dunia. Sebanyak 1 milyar orang di dunia atau 1 dari 4 orang dewasa menderita penyakit ini. Bahkan, diperkirakan jumlah penderita hipertensi akan meningkat menjadi 1,6 milyar menjelang tahun 2025. Kurang lebih 10$30 \%$ penduduk dewasa di hampir semua negara mengalami penyakit hipertensi, dan sekitar 50-60\% penduduk dewasa dapat dikategorikan sebagai mayoritas utama yang status kesehatannya akan menjadi lebih baik bila dapat dikontrol tekanan darahnya (Adib, 2009).

Badan Kesehatan Dunia (WHO) menyebutkan jumlah penderita hipertensi akan terus meningkat seiring dengan jumlah penduduk yang bertambah pada 2025 mendatang diperkirakan sekitar $29 \%$ warga dunia terkena hipertensi. WHO menyebutkan negara ekonomi berkembang memiliki penderita hipertensi sebesar $40 \%$ sedangkan negara maju hanya 35\%, kawasan Afrika memegang posisi puncak penderita hipertensi, yaitu sebesar 40\%. Kawasan Amerika sebesar 35\% dan Asia Tenggara 36\%. Kawasan Asia penyakit ini telah membunuh 1,5 juta orang setiap tahunnya. Hal ini menandakan satu dari tiga orang menderita hipertensi. Sedangkan di Indonesia cukup tinggi, yakni mencapai 32\% dari total jumlah penduduk (Widiyani, 2013). 
Menurut laporan Kemenkes (2013), bahwa hipertensi merupakan penyebab kematian nomor 3 setelah stroke dan tuberkulosis, dimana proporsi kematiannya mencapai 6,7\% dari populasi kematian pada semua umur di Indonesia. Hasil Riset Kesehatan Dasar (Riskesdas) Balitbangkes tahun 2013 menunjukkan prevalensi hipertensi secara nasional mencapai 25,8\%. Penderita hipertensi di Indonesia diperkirakan sebesar 15 juta tetapi hanya $4 \%$ yang hipertensi terkendali. Hipertensi terkendali adalah mereka yang menderita hipertensi dan mereka tahu sedang berobat untuk itu. Sebaliknya sebesar $50 \%$ penderita tidak menyadari diri sebagai penderita hipertensi, sehingga mereka cenderung untuk menderita hipertensi yang lebih berat.

Hasil Riskesdas tahun 2013 melaporkan bahwa prevalensi hipertensi di Sumatera Utara sebesar $45,69 \%$ pada kelompok umur di atas 60 tahun untuk penderita rawat jalan. Berdasarkan penyakit penyebab kematian pasien rawat inap di Rumah Sakit Kabupaten/Kota Provinsi Sumatera Utara, hipertensi menduduki peringkat pertama dengan proporsi kematian sebesar 27,02\% (1.162 orang), pada kelompok umur $\geq 60$ tahun sebesar 20,23\% (1.349 orang) (Kemenkes RI, 2013).

Berdasarkan survei awal pada bulan Januari 2015 di Puskesmas Pancur Batu yang memiliki wilayah kerja 22 desa ditemukan jumlah penderita hipertensi yang di rawat inap tahun 2013-2015 terus mengalami peningkatan. Jumlah penderita hipertensi tahun 2013, sebanyak 2.841 penderita, tahun 2014 sebanyak 2.855 penderita dan tahun 2015 sampai dengan bulan Juni sebanyak 1.250 penderita. Jumlah penderita hipertensi terbanyak di wilayah Kerja Puskesmas Pancur Batu tahun dari tahun 2013-2015 terdapat di Desa Hulu, yaitu tahun 2013 berjumlah 44 orang, tahun 2014 berjumlah 56 orang dan tahun 2015 berjumlah 108 orang. Dari 108 orang penderita hipertensi terdapat 38 orang penderita hipertensi yang berusia di atas 45 tahun, 4 orang penderita hipertensi diantaranya mengalami stroke ringan dan 1 orang penderita hipertensi mengalami stroke berat (Profil Puskesmas Pancur Batu, 2015).

Berdasarkan hasil wawancara terhadap beberapa penderita hipertensi terkait dengan terjadinya penyakit hipertensi sebagian besar tidak terlalu memahami asupan makanan yang harus di konsumsi, tingkat pendidikan tergolong rendah dan jarang terpapar dengan sumber informasi atau penyuluhan kesehatan yang harusnya dilakukan oleh petugas kesehatan atau kader puskesmas, ada pula penderita yang mengatakan agak repot kalau harus membuat makanan yang terpisah dari anggota keluarga lainnya, bahkan sebagian besar penderita tidak terlalu perduli dengan hipertensi yang dideritanya karena belum mengganggu aktivitas sehari-hari dan beranggapan tekanan darahnya akan normal kembali dalam beberapa hari, selain itu penyakit hipertensi di dapat juga sebagian dari faktor keturunan, sehingga tidak memanfaatkan fasilitas kesehatan walaupun jarak tempat tinggal dengan fasilitas kesehatan tidak terlalu jauh.

Berdasarkan latar belakang yang telah diuraikan, maka perlu dilakukan penelitian tentang pengaruh pengetahuan, sikap dan dukungan keluarga terhadap pelaksanaan 
diet hipertensi di Desa Hulu Kecamatan Pancur Batu tahun 2015. Sehingga penulis merumuskan bahwa apakah ada pengaruh pengetahuan, sikap dan dukungan keluarga terhadap pelaksanaan diet hipertensi di Desa Hulu Kecamatan Pancur Batu tahun 2015?

Adapun tujuan penelitian ini, yaitu untuk mengidentifikasi pengaruh pengetahuan, sikap dan dukungan keluarga terhadap pelaksanaan diet hipertensi di Desa Hulu Kecamatan Pancur Batu Tahun 2015.

\section{METODOLOGI PENELITIAN}

Jenis penelitian adalah Cross-Sectional Study dengan pendekatan explanatory. Penelitian ini dilaksanakan bulan April sampai Juni 2016. Populasi dalam penelitian adalah seluruh penderita hipertensi di Desa Hulu Kecamatan Pancur Batu berjumlah 108 orang dan seluruh populasi dijadikan sampel. Data diperoleh dengan wawancara menggunakan kuesioner, dianalisis dengan regresi logistik berganda pada a=0,05.

\section{HASIL DAN PEMBAHASAN}

Karakteristik responden dapat dilihat sebagai berikut :

Tabel 1.Distribusi Berdasarkan Karakteristik

\begin{tabular}{|c|c|c|c|}
\hline \multicolumn{2}{|l|}{ Karakteristik } & $\mathbf{n}$ & $\%$ \\
\hline \multicolumn{4}{|l|}{ Umur } \\
\hline $30-36$ tahun & & 18 & 16,7 \\
\hline $37-43$ tahun & & 46 & 42,6 \\
\hline $44-50$ tahun & & 44 & 40,7 \\
\hline \multicolumn{4}{|l|}{ Jenis kelamin } \\
\hline Perempuan & & 58 & 53,7 \\
\hline Laki-laki & & 50 & 46,3 \\
\hline \multicolumn{4}{|l|}{ Pendidikan } \\
\hline Tamat SD & & 7 & 6,5 \\
\hline SLTP & & 44 & 40,8 \\
\hline SLTA & & 52 & 48,1 \\
\hline Akademi/S1 & & 5 & 4,6 \\
\hline \multicolumn{4}{|l|}{ Pekerjaan } \\
\hline Ibu Rumah Tangga & & 35 & 32,4 \\
\hline Petani & & 49 & 45,4 \\
\hline $\begin{array}{l}\text { PNS/TNI/ Polri/ Pegawai } \\
\text { Pensiunan }\end{array}$ & swasta/ & 6,10 & 9,2 \\
\hline Wiraswasta/ Pedagang & & 14 & 13,0 \\
\hline Jumlah & & 108 & 100,0 \\
\hline
\end{tabular}

Karakteristik responden meliputi umur, jenis kelamin, pendidikan, dan pekerjaan. Hasil penelitian menunjukkan bahwa responden dengan umur terbanyak 37-43 tahun, yaitu sebanyak 46 orang $(42,6 \%)$. Jenis kelamin lebih banyak perempuan, yaitu 
sebanyak 58 orang $(53,7 \%)$. Pendidikan lebih banyak tingkat pendidikan SLTA, yaitu sebanyak 52 orang $(48,1 \%)$ dan berdasarkan pekerjaan lebih banyak petani, yaitu sebanyak 49 orang $(45,4 \%)$.

\section{Analisis Bivariat}

Pengaruh masing-masing variabel bebas, yaitu pengetahuan dan sikap serta dukungan keluarga. Adapun hasil uji secara statistik sebagai berikut:

Tabel 2. Pengaruh Variabel Bebas dengan Variabel Terikat

\begin{tabular}{|c|c|c|c|c|c|c|c|}
\hline \multirow{3}{*}{ Variabel } & \multicolumn{4}{|c|}{ Pelaksanaan Diet } & \multirow{2}{*}{\multicolumn{2}{|c|}{ Jumlah }} & \multirow{3}{*}{$P$} \\
\hline & \multicolumn{2}{|c|}{ Tidak Baik } & \multicolumn{2}{|c|}{ Baik } & & & \\
\hline & $\mathbf{n}$ & $\%$ & $\mathbf{n}$ & $\%$ & $\mathbf{n}$ & $\%$ & \\
\hline \multicolumn{8}{|l|}{ Pengetahuan } \\
\hline Tidak baik & 64 & 91,4 & 6 & 8,6 & 70 & 100,0 & \multirow[t]{2}{*}{0,001} \\
\hline Baik & 12 & 31,6 & 26 & 68,4 & 38 & 100,0 & \\
\hline \multicolumn{8}{|l|}{ Sikap } \\
\hline Negatif & 62 & 84,9 & 11 & 15,1 & 73 & 100,0 & \multirow[t]{2}{*}{0,001} \\
\hline Positif & 14 & 40,0 & 21 & 60,0 & 35 & 100,0 & \\
\hline \multicolumn{8}{|l|}{ Dukungan } \\
\hline Keluarga & & & & & & & \multirow{3}{*}{0,001} \\
\hline Tidak baik & 70 & 82,4 & 15 & 17,6 & 85 & 100,0 & \\
\hline Baik & 6 & 26,1 & 17 & 73,9 & 23 & 100,0 & \\
\hline
\end{tabular}

\section{Pengaruh Sikap dengan Pelaksanaan Diet Hipertensi}

Dari hasil penelitian pengaruh sikap dengan pelaksanaan diet hipertensi hasil uji statistik Chi-square diperoleh $\mathrm{p}<0,05$, hal ini menunjukkan ada pengaruh yang signifikan antara sikap dengan pelaksanaan diet hipertensi, artinya semakin positif sikap responden maka semakin baik pelaksanaan diet hipertensi. Hasil penelitian pengaruh dukungan keluarga dengan pelaksanaan diet hipertensi hasil uji statistik Chisquare diperoleh $\mathrm{p}<0,05$, hal ini menunjukkan ada pengaruh yang signifikan antara dukungan keluarga dengan pelaksanaan diet hipertensi, artinya semakin baik dukungan keluarga maka semakin baik pelaksanaan diet hipertensi

\section{Analisis Multivariat}

Analisis multivariat model regresi logistik berganda harus memenuhi persyaratan hasil pengujian. Persyaratan yang dimaksud, yaitu variabel independen yang disertakan ke dalam uji multivariat harus memiliki nilai uji statistik $p<0,25$ pada uji bivariat. Berdasarkan hasil uji bivariat dengan metode chi-square variabel pengetahuan, sikap dan dukungan keluarga memiliki nilai $\mathrm{p}<0,25$, sehingga variabel pengetahuan, sikap dan dukungan keluarga disertakan dalam uji regresi logistik. 
Tabel 3. Hasil Uji Regresi Logistik

\begin{tabular}{lcccccr}
\hline No Variabel & & & & & \multicolumn{2}{c}{$\begin{array}{c}95 \% \text { CI For } \\
\text { Exp. } B\end{array}$} \\
& & & df & Sig. & Exp.B & \multicolumn{2}{c}{ Lower } & Upper \\
\hline 1 Pengetahuan & 3,810 & 1 & 0,001 & 45,170 & 8,710 & 234,253 \\
2 Sikap & 2,267 & 1 & 0,008 & 9,655 & 1,826 & 51,051 \\
3 Dukungan keluarga & 1,866 & 1 & 0,020 & 6,463 & 1,348 & 30,982 \\
$\quad$ Constant & $-4,193$ & 1 & 0,000 & 0,015 & & \\
\hline
\end{tabular}

Pengetahuan mempunyai nilai Exp (B) sebesar 45,170, artinya responden yang memiliki pengetahuan baik mempunyai peluang 45 kali pelaksanaan diet hipertensi dengan baik dibandingkan dengan responden yang memiliki pengetahuan tidak baik. Nilai B = Logaritma Natural dari $45,170=3,810$. Oleh karena Nilai B bernilai positif maka pengetahuan mempunyai pengaruh positif terhadap pelaksanaan diet hipertensi. Sikap mempunyai nilai Exp (B) sebesar 9,655 artinya responden yang memiliki sikap positif mempunyai peluang 10 kali pelaksanaan diet hipertensi dengan baik dibandingkan dengan responden yang memiliki sikap negatif.

Nilai B = Logaritma Natural dari 9,655=2,267. Oleh karena Nilai B bernilai positif maka sikap mempunyai pengaruh positif terhadap pelaksanaan diet hipertensi.

Dukungan keluarga mempunyai nilai Exp (B) sebesar 6,463 artinya responden yang menyatakan dukungan keluarga baik mempunyai peluang 6 kali pelaksanaan diet hipertensi dengan baik dibandingkan dengan responden yang menyatakan dukungan keluarga tidak baik. Nilai B = Logaritma Natural dari 6,463=1,866. Oleh karena Nilai B bernilai positif maka sikap mempunyai pengaruh positif terhadap pelaksanaan diet hipertensi.

Dari ketiga Variabel pengetahuan, sikap dan dukungan keluarga yang mempunyai pengaruh lebih besar terhadap pelaksanaan diet hipertensi adalah pengetahuan.

\section{Pengaruh Pengetahuan terhadap Pelaksanaan Diet Hipertensi}

Berdasarkan uji statistik Chi-square menunjukkan ada pengaruh yang signifikan antara pengetahuan tentang pengertian diet hipertensi (pengaturan makanan) dan asupan makanan penderita hipertensi $(p<0,05)$. Hasil uji statistik multivariat pengetahuan berpengaruh positif dan signifikan terhadap pelaksanaan diet hipertensi $(\mathrm{p}<0,05) ; \operatorname{Exp}(B)=45,170 ; C I$ For $\operatorname{Exp}(B)(8,710-234,253)$. Hal ini memberikan makna bahwa responden yang memiliki pengetahuan baik tentang pengertian diet hipertensi (pengaturan asupan makanan) dan asupan makanan penderita hipertensi mempunyai peluang 45 kali pelaksanaan diet hipertensi dengan baik.

Hasil penelitian ini sejalan dengan hasil penelitian Abubakar (2007), Kusumawati (2014) dan Saputro (2009) menyimpulkan bahwa ada hubungan yang signifikan antara pengetahuan penderita hipertensi dengan pola makan sehari - hari, dari penelitian 
tersebut dapat diambil kesimpulan bahwa pengetahuan seseorang mempengaruhi tindakan yang akan dilakukan terkait dengan diet hipertensi. Demikian juga pada hasil penelitian Ginting (2006) dan Novian (2013) menyimpulkan bahwa ada hubungan antara tingkat pengetahuan dengan kepatuhan diet pasien hipertensi. Hasil penelitian ini didukung teori Green dalam Notoatmodjo (2010) yang menyatakan bahwa pengetahuan datang dari pengalaman dapat diperoleh dengan informasi yang didapat dan akan mempengaruhi sikap. Jika mempunyai pengetahuan tinggi, secara otomatis orang tersebut bersikap dan berperilaku yang sesuai dengan pengetahuannya.

\section{Pengaruh Sikap terhadap Pelaksanaan Diet Hipertensi}

Berdasarkan uji statistik Chi-square menunjukkan ada pengaruh yang signifikan antara sikap dengan pelaksanaan diet hipertensi $(p<0,05)$. Hasil uji statistik multivariat sikap berpengaruh positif dan signifikan terhadap pelaksanaan diet hipertensi $(p<0,05)$; nilai $\operatorname{Exp}(B)=9,655 ;$ CI For $\operatorname{Exp}(B)(1,826$ 51,051). Hal ini memberikan makna bahwa responden yang memiliki sikap positif terhadap diet hipertensi (pengaturan asupan makanan) dan pengaturan makanan diet hipertensi mempunyai peluang 10 kali pelaksanaan diet hipertensi dengan baik.

Hasil penelitian ini didukung hasil penelitian Busari, et al. (2010) di Nigeria menyimpulakn bahwa pengetahuan dan sikap pasien hipertensi mempengaruhi kepatuhan pengontrolan tekanan darah, dan angka morbiditas serta mortalitas penyakit hipertensi. Pasien yang memiliki pengetahuan baik tentang hipertensi dapat meningkatkan kepatuhannya dalam pelaksanaan program terapi. Demikian juga dalam hasil penelitian Runtukahu (2015), Puspita (2011) dan Ginting (2008) menyimpulkan bahwa terdapat pengaruh sikap terhadap kepatuhan diet hipertensi dengan tekanan darah pada penderita hipertensi. Hasil Penelitian ini juga didukung oleh teori Green dalam Notoatmodjo (2007) yang menyatakan bahwa sikap merupakan bagian dari faktor predisposisi yang berpengaruh dalam membentuk perilaku seseorang.

\section{Pengaruh Dukungan Keluarga terhadap Pelaksanaan Diet Hipertensi}

Berdasarkan uji statistik Chi - square menunujukkan ada hubungan yang signifikan antara dukungan keluarga dengan pelaksanaan diet hipertensi $(p<0,05)$. Hasil uji statistik multivariat dukungan keluarga berpengaruh positif dan signifikan terhadap pelaksanaan diet hipertensi $(\mathrm{p}<0,05)$; nilai $\operatorname{Exp}(B)=6,463$; CI For $\operatorname{Exp}(\mathrm{B})(11,348-$ 30,982). Hal ini memberikan makna bahwa responden yang mendapat dukungan keluarga dengan baik mempunyai peluang 6 kali pelaksanaan diet hipertensi dengan baik.

Hasil penelitian ini sejalan dengan hasil penelitian Nainggolan (2012) terkait pengendalian hipertensi yang dilakukan oleh keluarga terhadap 45 orang penderita hipertensi di poliklinik RSUD Tugurejo Semarang menyimpulkan bahwa terdapat hubungan yang signifikan antara dukungan keluarga dengan pelaksanaan diet rendah 
garam. Dari penelitian tersebut dapat disimpulkan bahwa dukungan keluarga sangat berperan dalam pengendalian hipertensi. Demikian juga pada hasil penelitian Kusumawati (2014) di wilayah kerja Puskesmas Mojopanggung Banyuwangi menyimpulkan bahwa terdapat hubungan yang positif dan signifikan antara dukungan keluarga dengan kepatuhan diet hipertensi.

\section{Pelaksanaan Diet Hipertensi}

Berdasarkan karateristik responden penderita hipertensi, yaitu sebanyak 46 orang $(42,6 \%)$ berumur 37 - 43 tahun dan sebanyak 44 orang $(40,7 \%)$ berumur $44-50$ tahun (90 orang berumur 37 - 50 tahun). Hipertensi tidak berbeda dengan penyakit degeneratif lain yang sering dialami seseorang sehubungan dengan bertambahnya usia. Hipertensi yang dianggap sebagai silent killer memang baru dirasakan akibatnya saat seseorang mengalami komplikasi dari meningkatnya tekanan darah dengan gejala gejala yang dianggap sepele seperti sakit kepala atau nyeri tengkuk. Hal ini sejalan dengan pendapat Mansjoer (2001) menyatakan bahwa umur lebih dari 40 tahun mempunyai resiko terkena hipertensi. Arteri kehilangan elastisitasnya atau kelenturannya dan tekanan darah seiring bertambahnya usia, kebanyakan orang mengalami hipertensi ketika berumur lima puluhan atau enam puluhan (Staessen et al, 2003).

Berdasarkan jenis kelamin penderita hipertensi lebih banyak perempuan, yaitu sebanyak 58 orang $(53,7 \%)$. Hal ini sejalan dengan pendapat Sustarani (2004) mengungkapkan bahwa wanita penderita hipertensi lebih banyak daripada laki - laki. Tetapi wanita lebih tahan daripada laki - laki tanpa kerusakan jantung dan pembuluh darah. Pria lebih banyak mengalami kemungkinan menderita hipertensi daripada wanita. Pada pria hipertensi lebih banyak disebabkan oleh pekerjaan, seperti perasaan kurang nyaman terhadap pekerjaan. Sampai usia 55 tahun pria berisiko lebih tinggi terkena hipertensi dibandingkan wanita.

\section{KESIMPULAN}

Berdasarkan hasil analisis data dan hasil penelitian maka diperoleh kesimpulan dalam penelitian ini yaitu ada pengaruh yang signifikan antara pengetahuan dan sikap serta dukungan keluarga terhadap pelaksanaan diet hipertensi yang dilihat dari nilai signifikan $(\mathrm{p}=0.001)$, sehingga $(\mathrm{p}<0.005)$, maka Ha diterima dan Ho ditolak, dengan kata lain pengetahuan responden yang baik dan sikap positif serta dukungan keluarga yang baik akan memiliki peluang pelaksanaan diet hipertensi dengan baik.

\section{DAFTAR PUSTAKA}

Adib., M., (2009). Cara Mudah Memahami dan Menghindari Hipertensi Jantung dan Stroke. Dianloka Dianloka Pustaka Populer, Yogyakarta. 
Bustan, M.N., (2007). Epidemilogi Penyakit Tidak Menular. Rineka Cipta, Jakarta.

Kemenkes RI, (2013). “Direktorat Jenderal PPM\&PLP, Pemberantasan Penyakit Menular dan Penyehatan Lingkungan" Jakarta.

Kusumawati, D. (2014). “Hubungan Pengetahuan Dan Dukungan Keluarga Dalam Pengaturan Diit Hipertensi Dengan Kepatuhan Diit Penderita Hipertensi Diwilayah Kerja Puskesmas Mojopanggung Banyuwangi". TESIS. Program Studi Magister Kedokteran Keluarga, Program Pascasarjana, Universitas Sebelas Maret Surakarta.

Nainggolan, DFP. (2012). “Hubungan Dukungan Keluarga dengan Kepatuhan Diit Rendah Garam dan Keteraturan Kontrol Tekanan Darah Pada Penderita Hipertensi di Poliklinik RSUD Tugurejo Semarang". Jurnal Ilmu Keperawatan dan Kebidanan. 1(2) Desember.

Notoadmodjo. (2010). Pendidikan Kesehatan dan Ilmu Perilaku. Rineka Cipta, Jakarta.

Puspita, A, (2011). “Sikap Terhadap Kepatuhan Diit Hipertensi Dengan Tekanan Darah pada Penderita Hipertensi di Wilayah Kerja Puskesmas Doro II Kabupaten Pekalongan. Seminar Nasional Keperawatan PPNI Jawa Tengah". jurnal.unimus.ac.id.

Runtukahu, R.F. (2015). “Analisis Faktor-Faktor Yang Berhubungan Dengan Kepatuhan Melaksanakan Diet Pada Penderita Hipertensi di Wilayah Kerja Puskesmas Wolaang Kecamatan Langowan Timur". Ejournal Keperawatan (e-Kp). 3(2) Mei.

Saputro, H.T, (2009). “Hubungan Tingkat Pengetahuan Pasien Tentang Hipertensi Dengan Sikap Kepatuhan Dalam Menjalankan Diit Hipertensi Di Wilayah Puskesmas Andong Kabupaten Boyolali". Skripsi. Fakultas Ilmu Kesehatan Universitas Muhammadiyah Surakarta.

Widiyani, R., (2013). "Penderita Hipertensi Terus Meningkat". http://health.kompas.com/read/2013/04/05/1404008/Penderita.Hipertensi.Terus .Meningkat . Tanggal akses 21 Nopember 2014.

Varney, H, dkk. (2007). Buku Ajar Asuhan Kebidanan. Jakarta : EGC.

Walyani, E. S. (2015). Asuhan Kebidanan pada Kehamilan. Yogyakarta: Pustaka Barupess. 